\title{
Music, Meaning, and Sociality: From the Standpoint of a Social Phenomenologist
}

\author{
Andreas Goettlich
}

\section{Introduction}

The following article examines some rather fundamental thoughts on the connection of music, meaning, and sociality and to this end employs phenomenological reflections presented by Alfred Schutz in his writings about music. These texts reveal a specific epistemological interest which mirrors Schutz's professional background. As a social scientist he was interested in the social aspects of music, that is, he was primarily concerned with the act of intersubjective understanding by means of musical communication and he was considerably less concerned with the antecedent creation of musical meaning by the solitary individual. When regarded from this perspective, Schutz's reflections about music can be seen as instructive in adumbrating the general borderline between sociological and phenomenological research.

\section{Music and Meaning}

My reflections start with a simple observation: It is striking that two of the texts Schutz wrote about music - "Fragments toward a Phenomenology of Music" written in 1944 and "Making Music Together" written in 1951 - share a nearly identical beginning. "Fragments" starts with the assertion that "a piece of music is a meaningful context" (see Schutz 1996, p. 243) and the first sentence of "Making Music Together" is: "music is a meaningful context" (see Schutz 1964, p. 159). This

\footnotetext{
A. Goettlich ( $\square)$

University of Constance, Constance, Germany

e-mail: andreas.goettlich@uni-konstanz.de
} 
statement, therefore, must have been of some importance for Schutz, and as such is a logical starting point for a consideration of his position vis à vis music and sociality.

"Music is a meaningful context" - how can one understand this assertion? On a formal level one can regard it as either an observation or a definition. As an observation it would refer to an inductive generalization; according to the rules of logic one could interpret it as the idea that all the phenomena subsumed under the term "music" are meaningful, as far as we have empirical knowledge of them. Such an interpretation would hardly be adequate. It would mean that there is the possibility of finding musical phenomena which are not meaningful. Such an assumption not only contradicts our common sense conception of music, it is also obviously an inadequate paraphrase of what Schutz wanted to express with his statement.

As an alternative one can regard "music is a meaningful context" as a definition. As such it would exclude a priori the possibility of finding musical phenomena without meaning; the statement would be irrefutable. This may seem rather selfevident, yet phenomenological reflection shows that the alleged essential connection between music and meaning is not as straightforward as it first appears. It is a rather complex matter into which this paper tries to gain some insight. To this purpose, Schutz's writings about music are used as a central point of reference, whereas at a certain point reflections will go beyond them.

If one looks at Schutz's statement as a definition, one must agree that it is deficient. Although it follows the formally correct structure of definitions (which is: genus proximum, differentia specifica), it fails in its content since it designates neither the nearest genus, nor the specific difference: "Context" is too broad a category, and "meaningfulness" is also true of other contexts. To clarify the former, one could try to further explain the definition, for instance: Music is a sound, or a sequence of sounds, provided with meaning. Since the same can be said of spoken language, one has to further clarify: Music is a meaningful sound, but the meaning is not expressed in words. Schutz himself makes an equivalent exception when he writes that "music is not bound to a conceptual scheme" (1964, p. 159). ${ }^{1}$

With reference to the genus proximum "sound" seems to be a more adequate concept than "context." But how about the differentia specifica? What exactly is the specific difference between sound and music? Mentioning meaning is not enough since this would imply that other sounds aside from music (and speech, which has already been excluded above) are not meaningful. This is obviously incorrect: The piping of my water pot means that the water is boiling, and the beeping of my computer means that it is about to give up the ghost. Accordingly, the definition needs to be made more precise and reflect the specific kinds of meanings of music in opposition to the meanings of mere sounds.

\footnotetext{
${ }^{1}$ This seemingly self-evident containment may not be forgotten, as for example in Blaukopf's definition of musical action: "action aiming at the production of sonic incidents and containing a meaning which is oriented towards the behavior of others." (in German: "das auf die Erzeugung von Schallereignissen gerichtete Handeln mit einem auf das Verhalten anderer intendierten Sinn" (Blaukopf 1996, p. 3). This characterization is also true of speech and therefore unspecific.
} 
Using Schutz's theory of signs and symbols as a basis (cf. Schutz 1962), one can differentiate between three possible meanings of music: an indicative meaning, an emblematic meaning, and a symbolic meaning. In the first case, music is understood as an indication, overcoming so-called "Small Transcendencies"2; in the second case as a sign, overcoming so-called "Medium Transcendencies"3; in the third case as a symbol, overcoming so-called "Great Transcendencies." 4 According to the "Principle of the Relative Irrelevance of the Vehicle" (cf. Schutz 1962, p. 303), music may be used as an indication as well as a sign or a symbol. As a means to overcome a "Small Transcendency" it is used for instance in the case of the clock radio: The music simply "reminds" me to get up and does not (necessarily) have any further meaning. However, there can be no doubt that this is not the original or specific meaning of the music. The clock radio is just a further development of the alarm clock and designates some kind of misappropriation of the intrinsic purpose of music. Hence we may treat the indicative meaning of music as derivative. Furthermore, this meaning would not supply a distinctive criterion since music shares this potential meaning with sound. The same applies to the emblematic meaning. A musical expression of my fellow-man tells me something about his actual state of mind, but in the same way the sound of his gnawing teeth may also give me a hint concerning his mental state. As a consequence, the distinction between sound and music must be sought in its symbolic meaning. Music, in opposition to mere sounds, has the principal capability to overcome a "Great Transcendency." In other words, music is an acoustic phenomenon occurring within the paramount reality and referring - at least potentially - to a transcendent sphere of reality, that is, the world of arts. ${ }^{5}$ It is this third potential meaning which distinguishes music from mere sounds.

Now the talk of "potential" might be criticized as being airy and therefore unsatisfactory, but this vagueness actually refers to a fundamental issue. In order to distinguish whether a certain phenomenon falls under the category of sound or of music, it is not sufficient to look at the acoustic object alone. One rather has to consider the individual who experiences the phenomenon. This essential aspect is reflected in a verse by the German poet Wilhelm Busch: "music is often experienced as unpleasant since it is always connected with noise." ment by saying that music is not only inherently connected with noise; it might even be experienced as mere noise, depending on the listener and his situation. The verse, then, reveals a critical consideration: What for some may be an aesthetic experience,

\footnotetext{
${ }^{2}$ I.e., transcendencies of time and space (cf. Schutz and Luckmann 1989, pp. 106ff.).

${ }^{3}$ I.e., transcendencies of intersubjective communication (cf. Schutz and Luckmann 1989, pp. 109ff.).

${ }^{4}$ I.e., transcendencies of different spheres of reality (cf. Schutz and Luckmann 1989, pp. 117ff.).

${ }^{5}$ To be sure, there are sounds sometimes said to have symbolic meaning, such as, for instance, the singing of the blackbird. Yet, I would treat such modes of speaking as semantic derivations which, in the end, point back to music as the original phenomenon.

${ }^{6}$ In German: "Musik wird oft nicht schön gefunden, weil sie stets mit Geräusch verbunden." (see Wilhelm Busch: Der Maulwurf).
} 
can be pure annoyance for others. So in order to recognize an acoustic phenomenon as music - that is, as actualizing the third potential described above - the listener must adopt a certain attitude. ${ }^{7}$ In asserting that listening to music presupposes the "decision to listen to pure music," (Schutz 1996, p. 258) that is, to interpret a sequence of tones as music and not as noise, Schutz reflects this consideration. As with spoken language, an intention to understand what one hears is the necessary precondition for becoming aware of the meaning of music. One important consequence of this reflection is that the question whether a certain acoustic phenomenon may be categorized as music cannot possibly be answered a priori but only empirically.

By now, reflection has arrived at an insight which can be identified as a phenomenological matter of course: An adequate analysis of the musical phenomenon must reflect the individual experiencing it. Such a reflection can take advantage of a basic differentiation between three typical roles within which an individual may deal with musical meaning: (1) as a listener, e.g., sitting in a concert hall or listening to his iPod; (2) as a musician, that is, as member of an ensemble or as soloist; (3) as a composer. Certainly, the listener, the musician and the composer are ideal types created for analytic purposes. In reality, the musical performer usually simultaneously listens to the music he and his fellow-musicians play, and the act of playing music may coincide with the act of composing as with improvised music. Nevertheless, the typification helps to structure a phenomenological reflection about music and will be used as a means of differentiation for the rest of this paper. In an implicit way, one can uncover this typification within Schutz's writings about music. "Fragments" is primarily concerned with the listener, whereas "Making Music Together" deals primarily with the musician. However, there is no text in which Schutz focuses solely on the composer. ${ }^{8}$

Converse to the "natural" order, I will begin with the listener, who, in a manner of speaking, stands at the end of the chain of musical activities. Afterwards I will discuss the musician as type and finally the composer, and, thereby, inevitably go beyond Schutz.

\section{The Listener}

Within the framework of ideal types, as explained above, the listener is conceived as an individual perceiving a piece of music which, in that very moment, is being or previously has been performed by someone else. ${ }^{9}$ As such, the listener of music is

\footnotetext{
${ }^{7}$ To do so is not always under the listener's command. Cultural knowledge, normative aesthetic reflections, and even physical condition are all also involved. We know, for example, that in the US-Prison at Guantanamo Bay, popular music, which a lot of people enjoy and pay for, was used to torture the captives.

${ }^{8}$ There are, however, widespread remarks concerning the composer in Schutz's texts.

${ }^{9}$ In the case of a live performance the acts of performing and listening may take place (almost) synchronically, thus the argument is logical rather than temporal.
} 
concerned with the reconstruction of the meaning that was conferred on a piece of music by his fellow-man. He is not involved in the construction of this meaning. ${ }^{10}$

In "Fragments," Schutz develops a conception of how the listener becomes aware of the "correct" meaning of a piece of music. According to Schutz, the experience of listening to a piece of music takes place in the inner time of the listener, in his "durée" (cf. Bergson 1999). From the phenomenological point of view, listening to music cannot be adequately described by means of a natural scientific vocabulary: "the relations between sounds and mathematical proportions cannot even contribute anything to the questionable problem" (see Schutz 1996, p. 246). Instead, Schutz treats music as a kind of "ideal object," which, in a certain sense, exists independently of its physical features as they occur within outer time. To understand the reconstruction of the meaning of music, one must look at the inner procedures happening within the consciousness of the listener. For Schutz, the passing of time is a precondition for grasping the constituted meaning of a work of music; it can only be understood "by reconstituting the polythetic steps in which it has been built up, by reproducing mentally or actually its development from the first to the last bar as it goes on in time" (Schutz 1996, p. 248). In other words, in order to understand music in an emphatic sense, one must live through it, that is, one must synchronize one's inner time with that of the performer or composer, since by looking at a piece of music as a whole, one can only grasp the general content or mood of that piece.

Thus, the meaning of a piece of music constitutes itself in the stream of time, but we cannot recognize this meaning "as long as we follow the stream" (Schutz 1996, p. 267). Instead we have to step outside the stream. Schutz writes, "an experience while occurring, that is, while we are living in it, does not have any meaning; only the past experiences toward which we may turn back, are meaningful" (Schutz 1996, p. 271). Therefore, the constitution of musical meaning becomes a problem of a specific reconstruction by the listener. This line of reasoning leads to a problematic conclusion, namely, that one can understand music only after listening to it by directing the intentionality of one's consciousness back towards what has already happened in the past, while in the actual process of listening one does not understand the music in question.

This conclusion is wrong in the cursory sense, but right in a more subtle sense. Schutz's reasoning is that the listener is principally able to understand music while listening to it. The listener is enabled to do so with the use of "themes" or musical units, which imply "a feeling of virtual finality" (Schutz 1996, p. 270). Schutz's thesis states that a sequence of tones is experienced as a melody if it moves the beholder into a state of mind in which he can settle down and come to a rest. The completion of a musical theme or a melody provides a "resting place" (cf. James

\footnotetext{
${ }^{10}$ N.B, this statement refers to the ideal type. The listener who communicates his interpretation of the piece of music after listening to it (e.g. as a critic) or even while listening to it (e.g. as a dancer), surely takes part in the construction of musical meaning; this, however, is outside the scope of this analysis.
} 
1981, p. 236) from which the listener - whilst listening to the music - can "look back" at the elapsed time and make sense of it. As an example, Schutz refers to the theme of the last movement of Brahms' First Symphony:

To me personally ... this peculiar theme is the key to the understanding of Brahms' First Symphony. That is what I know by previous experiences. If the first notes of the beginning of the first movement start, I am directed by my anticipations toward the French horn theme which will appear later on at the end of the introduction of the fourth movement. All the preceding occurrences in the symphony receive, to me, their peculiar meaning and significance because I know that they will lead to this theme, all the events that follow derive their meaning from it. ... Thus, to me, this peculiar theme functions as a kind of home-position which may be reassumed any time if I am listening to this symphony or reproducing it before my inner ear (see Schutz 1996, pp. 267f.).

\section{The Musician}

In discussing the musician, I am referring - as Schutz does in "Making Music Together" - to the ideal-type of an individual making music as a soloist or as member of a group, thereby interpreting a score that was written sometime prior, either by the musician himself or by someone else. I am neither concerned with the case of the improvising musician, who composes while he is playing, nor with the practitioner, who is primarily occupied with improving his motor skills. ${ }^{11}$

In considering this ideal-type, we can observe the construction of musical meaning as opposed to its reconstruction as performed by the listener. Schutz's core argument identifies the act of making music together as a paradigmatic example of a "mutual tuning-in relationship," (see Schutz 1964, p. 161) that is, a basic kind of relationship upon which the communicative process is founded. The constitution of such a relationship presumes that the individuals involved in it "are growing older together" (Schutz 1964, p. 175).

This is obviously true of the members of a band or an orchestra making music together. But for Schutz, this can also be said of the composer and the performer, even if they live in different epochs. This works because the "mutual tuning-in" in question does not so much refer to objective time but rather to inner time, to "durée," as mentioned above. This differentiation allows Schutz to conceptualize the relationship between composer and performer as derived from a face-to-face relationship.

Composer and performer, as well as fellow-musicians, both experience the evolving of a piece of music in time, they both experience its step-by-step occurrence. It is this polythetic process which constitutes the meaning of a piece of music and it is

\footnotetext{
${ }^{11}$ A similar (I would say: ideal-type) exclusion is made by Schutz in "Making Music Together" when he assumes "that our piano player is equally proficient as a technician and sight reader and that consequently no mechanical or other external obstacle will hinder the flux of his performance" (see Schutz 1964, p. 167). It seems quite clear that especially the latter presupposition only holds true for a small minority of musicians and musical events.
} 
irrelevant whether two individuals live through this process at the same (outer) time or at different (outer) times, notwithstanding the fact that "making music together is an event in outer time" (Schutz 1964, p. 177). The crucial point is that the partners live through the same process with regard to their "durées" and that they establish simultaneity between their streams of consciousness. Schutz's core thesis states "that this sharing of the other's flux of experiences in inner time, this living through a vivid present in common, constitutes ... the mutual tuning-in relationship, the experience of the 'We,' which is at the foundation of all possible communication" (Schutz 1964, p. 173). ${ }^{12}$

Schutz's conclusions about the specific kind of social relationship existing between fellow-musicians or between composer and performer, which are only adumbrated here, sufficiently enough for our purposes, lead him to a more refined definition of music:

[A] piece of music may be defined ... as a meaningful arrangement of tones in inner time. It is the occurrence in inner time, Bergson's durée, which is the very form of existence of music. The flux of tones unrolling in inner time is an arrangement meaningful to both the composer and the beholder, because and in so far as it evokes in the stream of consciousness participating in it an interplay of recollections, retentions, protentions, and anticipations which interrelate the successive elements. (Schutz 1964, p. 170)

\section{The Composer}

Within the given context, the composer type is conceived as a person composing alone, not as part of a group. ${ }^{13}$ This specific interest in the lonesome composer has to be viewed against the background of the ideal typification, since in this context we can observe the constitution of subjective meaning (Sinn) without the construction of objective meaning (Bedeutung) (cf. Luckmann 2007c, pp. 142f.). As observed above, Schutz's discussion of musical meaning has a specific focus; this becomes evident in the passage cited above (cf. Schutz 1996, pp. 267f.), in which Schutz writes about "previous experiences," "preceding occurrences," and "reproducing." All of these phrases most obviously refer to the listener of music who is trying to reconstruct a meaning that has previously been established. This latter feature applies analogously to the case of the musician who performs a piece of music using

\footnotetext{
${ }^{12}$ Taking the listener into consideration as well, the relationship in question might be enhanced to a threefold correlation. In this context, the musician acts as a mediator between composer and listener (cf. Schutz 1964, p. 174).

${ }^{13}$ This is typical of much of the music relegated to the so-called classical music genre, be it from the Baroque period, Viennese Classicism, or Romantic period. In modern, especially popular music, things seem to be different as song writing credits are often given to several composers or even whole bands. However, when viewed more closely, the incidence of people composing as a team is smaller than the practice of credit-giving suggests. We know for example that the "congenital" writing team Lennon/McCartney wrote fewer songs in cooperation than has been supposed for a long time.
} 
an already existing score (or reproducing from memory). Generally, one can say that the music Schutz is concerned with, as well as its meaning, is "already there" as it has been previously performed and composed. This observation raises a significant question: Can one view the constitution of the meaning of music as performed by the composer in the same way that one views the constitution of the meaning of music as performed by the listener? Does the finding of musical meaning proceed in the same way as its reconstruction?

As will be shown in the following, there is a specific difference, a difference that implies a general borderline between phenomenological and sociological research. I should warn that the following argument is based neither on empirical analysis, nor on the introspective reflection of a practicing composer, which I am not. So one could call what follows speculation, and justifiably so. Nevertheless, I hope (and think) it constitutes an educated guess.

The initial impetus for these reflections came from a Monty Python sketch in which John Cleese imitates Ludwig van Beethoven composing the musical theme of his Fifth Symphony, the so-called Schicksalssymphonie. ${ }^{14}$ Although this sketch is certainly not meant to authentically depict the compositional act, it contains some thought-provoking implications for phenomenological reflection. Due to repeated disturbances by his wife, Cleese/Beethoven is not immediately able to arrange the tones in the right order. Sitting at his piano, he composes by trial and error and fails again and again in his attempts to complete the sequence G-G-G-bE F-F-F-... In Schutz's words, one can say that Cleese's/Beethoven's failure to complete the melody means that he cannot provide a resting place in the sense of William James, that is, a place from which the listener could grasp the meaning of the music he is listening to. Therefore the compositional attempts of Cleese/Beethoven remain meaningless, for the time being.

Yet eventually, more or less by accident, the composer hits the right note on his piano: G-G-G-bE is followed by F-F-F-D - thus producing the Fifth Symphony's famous initial theme with the specific meaning it has attained for literally millions of listeners. In the same way that Cleese/Beethoven knew of the mistakenness of his previous efforts, he instantly recognizes that he has found the appropriate tone and shouts, "I got it!" The composer realizes his success in the very moment he hits the right tune. His exclamation is reminiscent of the one apocryphally attributed to Archimedes when he found what would later be known as Archimedes' Principle, and allegedly shouted, "Eureka!" 15

As delineated above, the sketch conveys a twofold notion of composing. On the one hand, it is clear that the composer is creating something new: a sequence of tones played in a specific tempo and with specific phrasing; that is, a musical theme which comes into existence in the very moment the composer plays it for the first time; it is not there before. On the other hand, in a certain sense, the meaningful melody is already there before the composer manages to arrange the

\footnotetext{
${ }^{14}$ Monty Pythons Flying Circus, Episode 21.

15"I have found it!".
} 
precise tones in the right sequence. This is suggested by the fact that the composer can easily discriminate between those series of tones which are wrong and the one which is right. This circumstance could hardly be explained if we were to assume that the composer creates a meaningful melody ex nihilo, since, if that were the case, he would be completely free in his aesthetic judgment. Instead the notion of composition presented here is that of a melody already existing in some idealistic sense and waiting for its discovery by a composer.

Thus, two undertakings are referred to in the act of composing: creation and discovery. This somehow paradoxical situation was succinctly expressed by Ian Anderson, the noted rock musician, when he remarked that "music isn't there, it's bloody hard to find!" Thus, he expresses the idea that music is both the result of a creation of something totally new, as well as an "ideal object" which is already there - otherwise it would not make sense to search for it.

Given that this description of the compositional process is essentially correct, ${ }^{16}$ the reflection raises the question of how one may conceive of an already existing musical theme even before it is composed, without stepping into the field of metaphysical speculation. The phenomenological concept of epoché, i.e., the bracketing of ontological statements about the world (cf. Husserl 1989, §32), offers an adequate platform from which to answer this question. The method of epoché remains within the limits of epistemological reflection so that the talk of an "existing" musical theme does not mean that this theme has some antecedent ontic existence. It merely means that the composer, in his mind, imagines the theme as something which is already there.

While it is not possible to present a causal explanation for this description of, what I hold to be, a key notion in the act of composing, it is still possible to give evidence in support of it. To that end I will leave the theory of Alfred Schutz and move to the anthropological theory of Helmuth Plessner as explicated in his book Die Stufen des Organischen und der Mensch. Unfortunately there is not yet an English translation of this book, so the reader will have to be content with my imperfect translation of some passages from Plessner's book. In English the title of his book is roughly The Stages of the Organic World and Man. Plessner writes:

The secret of creation, of the idea consists in the fortunate grasp, in the encounter between man and things. Searching for something which is predefined is not the prius of invention in the intrinsic sense, since he who is searching for something, in truth has already found. $\mathrm{He}$ falls under the law of that-which-is-being, according to which, discovery is only the fulfillment of a pursuit that is satisfiable by guarantee. The prius of searching and finding,

\footnotetext{
${ }^{16}$ The description is directed against a conceptualization of composing as a mere following of rules. Of course there are musical structures, patterns, and forms, which, in a certain sense, determine the act of composing; once a composer has decided how to start a piece of music, many of the following decisions are already anticipated. For example, the symphony's form constricts the composer in how he can handle his musical theme. But in order to find such a theme, musical patterns, forms, and structures cannot help. They certainly aid in bringing the musical ideas together into an aesthetic whole, that is, in the act of composing in the literal sense. Yet there is no musical rule that says: "after G-G-G-bE, F-F-F-D has to follow." This parallels linguistic syntax since syntax prescribes how to build sentences out of words, but not how to find new words.
} 
however, is the correlativity of man and the world, which refers back to the identity of his excentric form of position and the structure of the material world. (Plessner 1975, p. 322, the author's translation) $)^{17}$

In the part of his book from which the passage is taken, Plessner does not talk explicitly about musical composition; he is more concerned with craftsmanship in general. But one may apply his thoughts to the topic at hand without serious theoretical problems. I will only give a very brief outline of the arguments behind Plessner's anthropological theory. He distinguishes human beings from plants and animals as the alternative forms of organic life on earth by referring to their positionality which is different for each. According to Plessner humans are characterized by their "excentric positionality," (cf. Plessner 1975, pp. 288ff.) that is, they possess - in contradistinction to plants - a positional centre, through which contact to the outer world is mediated. This mediation grants humans a form of independence from their environment. The latter is also true of animals, but while animals live in this mediation, a human being's positional centre relates not only to the environment but also to itself, so that humans are able to become aware of the mediation in which they stand. Walter Schulz, a pupil of Plessner, later spoke of "mankind's fractured relation to the world," (cf. Schulz 1994) ${ }^{18}$ thereby expressing Plessner's idea that the relation of humans to the outer world and even to their inner world is principally ambiguous and full of friction.

From these basic assumptions Plessner deduces three "fundamental anthropological laws," one of which he calls the "Law of Mediated Immediacy" (cf. Plessner 1975, pp. 321ff.). ${ }^{19}$ It states that human beings are able to find direct contact to the outer and inner world only by mediating this same contact, that is, by making it an indirect one. Since this ambiguity is based on the position of mankind in the world, it is also valid in reference to the relation between the artist and his work of art. He, the artist, conceives of this relation in a twofold sense: On the one hand, he thinks of his artwork as something which originated from himself and is an outcome of his own intentions. On the other hand, he reflects his artwork as some "ideal object," as Schutz calls it, as an object which is imagined as something existing independently of his doing, as something which he only materializes. ${ }^{20}$ Only within this ambiguity can the artist fulfill his artistic ambition, and only when his subjective intention and

\footnotetext{
${ }^{17}$ In German: "Das Geheimnis des Schöpfertums, des Einfalls besteht in dem glücklichen Griff, in der Begegnung zwischen dem Menschen und den Dingen. Nicht das Suchen nach etwas Bestimmtem ist das Prius der eigentlichen Erfindung, denn wer nach etwas sucht, hat in Wahrheit schon gefunden. Er steht unter dem Gesetz des Seienden, nach welchem der Fund die bloße Erfüllung eines garantiert erfüllbaren Strebens ist. Das Prius von Suchen und Finden dagegen ist die Korrelativität von Mensch und Welt, die auf die Identität seiner exzentrischen Positionsform und der Struktur dinglicher Realität ... zurückweist."

${ }^{18}$ In German: "gebrochener Weltbezug."

${ }^{19}$ In German: "Gesetz der vermittelten Unmittelbarkeit."

${ }^{20}$ This notion of an artwork "being there" even before it is created is expressed quite clearly by a famous dictum (allegedly) by Michelangelo that says that the secret of statuary consists in removing those parts of the stone that are superfluous.
} 
the configuration of the objective world collide can the artist find fulfillment. This is what Plessner means when he speaks of a "fortunate grasp." He therefore concludes: "what enters into the sphere of culture, shows ligation to human creatorship and at the same time (and to the same extent) independence from it. Man can only invent insofar as he discovers" (Plessner 1975, p. 321, the author's translation). ${ }^{21}$

\section{Conclusion: The Borderline Between Sociology and Phenomenology}

As the above discussion of the composer demonstrates, Schutz's reflections on music do not consider all three types of individuals who are concerned with the meaning of a piece of music. Indeed Schutz explains in a convincing manner the process of mediation of musical meaning in intersubjective contexts, that is, between the composer and performer, the musician and the listener, or between fellowmusicians, but his writings about music do not describe how this meaning initially comes into being. I therefore attempted to elucidate this creative act with reference to the positionality argument of Helmuth Plessner.

Yet Schutz's limiting his arguments and observations to only certain aspects of the phenomenon under scrutiny should not be viewed as some kind of deficiency; rather, I think that this limitation in the scope of his argument is for good reason. In his writings about music Schutz clearly stays within the realm of "Interpretive Sociology" in that he considers music primarily as a social phenomenon. The understanding of the meaning of a piece of music, therefore, has to be conceived as an act of interpersonal communication. The objective of an "Interpretive Sociology" of music is to find out about how this act of communication works. To this question, I think, Schutz has provided a worthwhile answer.

What lies beyond the realm of communication is the aesthetic act of composing, which here means creating or finding a meaningful arrangement of tones. This is not a genuine social action. According to the famous definition given by Max Weber, a certain action is to be called social "insofar as its subjective meaning takes account of the behavior of others and is thereby oriented in its course" (see Weber 1978, p. 4). Weber's definition implies that composing is not first and foremost a social action, at least not if one focuses on the act of finding the "right" tune. This action is guided by aesthetic ideals, not by reflecting on the possible reaction of others to a subsequent musical performance which may never happen. Schutz certainly was aware of this when he wrote, "it is clear that from the point of view of the composer a musical thought may be conceived without any intention of communication" (see Schutz 1964, p. 164); the composer might create his work "only as an expression of his musical thoughts" (Schutz 1964, p. 170).

\footnotetext{
${ }^{21}$ In German: "Was also in die Sphäre der Kultur eingeht, zeigt Gebundenheit an das menschliche Urhebertum und zugleich (und zwar in demselben Ausmaß) Unabhängigkeit von ihm. Der Mensch kann nur erfinden, soweit er entdeckt."
} 
Of course, when I maintain that composing is not a genuine social action, I am referring specifically to the primordial act of musical interpretation, that is, the finding of a meaningful sequence of tones, the "musical unit" to which Schutz attaches such great importance. ${ }^{22}$ Certainly, the compositional processing of such a theme has to be conceived of as social action. The composer must reflect how an anonymous, or in some cases concrete, performer will interpret his score, be it a member of a band or an orchestra, or a soloist. He may also take into account the possible reactions of an audience. Moreover, the context in which composing takes place is always a social context and cannot be adequately conceived otherwise. The very moment a composer begins to implement his idea in the working world (Wirkwelt), he makes use of the activities of his fellow-men: The pencil he uses to write down his thoughts is a social product as is the paper on which he writes, the notation system he uses has been invented by someone else, and he presupposes that the appropriate knowledge required to decipher his signs is distributed within society or at least within the "society of musicians" (Schutz 1964, p. 163). Even if he does not produce a score at all, he uses an instrument that was built by a craftsman whose work rests upon the theoretical and practical knowledge of generations of instrument builders before him. Even the composer's "knowledge" about what can be regarded as an aesthetically adequate means of artistic expression is socially derived. Yet at the very moment of creating a musical theme as the core element of a song, symphony, or whatever, all these aspects do not have any relevance within the mind of the artist - he just wants to get tunes right.

According to this argument, it is understandable that Schutz was primarily concerned with the types of the listener and musician, and less with the type of the composer in his writings about music. As a sociologist, he was interested in music as a social phenomenon, that is, in the intersubjective mediation of musical meaning. In contradistinction, the solitary (in an ideal-type sense) act of finding a meaningful melody was not the focus of Schutz's sociological studies. This act is logically antecedent to musical communication, since meaning has to be created or discovered by a single person before it may be conveyed to others. Music first has to make sense to the composer before it can gain meaning within a musical community. Once again Helmuth Plessner provides an anthropological corroboration of the circumstance in question: "the creative grasp is an activity of expression," (Plessner 1975 , p. 322, the author's translation $)^{23}$ he writes, and he adds that the necessity to express oneself at all necessarily comes prior to the forms of expression (cf. Plessner 1975, p. 323).

On a more abstract level the consideration of the topic of musical meaning illustrates the general borderline between sociology and phenomenology. Schutz draws from phenomenological reflections in order to solve sociological problems and this epistemological interest of his is what shapes his use of phenomenological propositions. In expanding of the theory of Alfred Schutz with aid of the writings

\footnotetext{
${ }^{22}$ See his statement about Brahms's First Symphony above (Schutz 1996, pp. 267f.).

${ }^{23}$ In German: "Der schöpferische Griff ist eine Ausdrucksleistung."
} 
of Helmuth Plessner, it becomes clear that phenomenology can continue where sociology loses the interest of its specific discipline, since phenomenology can be used to analyze all kinds of human phenomena, whereas sociology restricts itself to those which are of a social nature. ${ }^{24}$ Thus, the border between phenomenology and sociology can be seen as the line where sociological investigation ends, and, as a consequence, sociological theory rests upon philosophical propositions for which it cannot offer any proof. For example, the fact that the listener is able to understand the subjective meaning that Beethoven connected with the theme of his Fifth Symphony - thereby constructing objective meaning - cannot be explained by sociological reflection alone. It rests upon the assumption that human beings approximately react in the same way when listening to a piece of music. It also rests on the assumption that they tend to accept the same melodies (in our case the succession of two thirds) as "resting places." It presupposes - as Schutz formulates with reference to George H. Mead - "that a prelinguistic 'conversation' of 'attitudes' is possible," (see Schutz 1964, p. 161) or in other words that there is some kind of reciprocity of perspectives. Why such reciprocity exists at all, is a question which goes beyond the explanatory scope of sociology.

On the other hand, phenomenology cannot provide the empirical knowledge that sociology as a Wirklichkeitswissenschaft is able to give. ${ }^{25}$ Sociologists possess the scientific instruments to empirically enhance the necessarily abstract theorems of phenomenology by applying them to concrete socio-historic situations. In order to make the otherwise rather vague concept of reciprocity concrete, one has to empirically describe social circumstances that bring forward (or do not) the supposition of reciprocity. Only this type of scientific work has the ability to yield real insight into empiric phenomena, to explain them in the strictest sense of the word. For example, the statement that a certain piece of music is designed to achieve a synchronization of the "durées" of the musician and the listener, cannot possibly explain why it becomes (or does not become) popular in specific cultures and at specific times. In order to explain this, one must leave the abstract level of phenomenological reflection and plunge into the cultural diversity of social life. In this sense, sociology goes on where phenomenology ends.

Having come to this conclusion, I would like to make my last point by commenting on an argument Thomas Luckmann provided some decades ago. In an article about the relation between phenomenology and sociology, he argues that the border between the two disciplines is drawn by a difference of both perspectives and methods. While the phenomenological perspective is egological, the sociological one is cosmological; and while the method of phenomenology is reflexive, the one of

\footnotetext{
${ }^{24}$ It may be worth mentioning that this distinction does not collide with the one given by the editors in the introduction. Their definition focuses on the difference of methodological approaches, whereas here emphasis is given to the difference of subject matters.

${ }^{25}$ Nota bene: This statement refers to Husserlian phenomenology in the way it was performed by himself, that is, as a founding of the factual sciences (this is also Luckmann's understanding of Husserl; see below). Indeed, Husserl also mentions the idea of an empirical phenomenology that follows the eidetic one (Husserl 1962, p. 298).
} 
sociology is inductive (cf. Luckmann 1979, p. 196). In light of the above arguments, one may also add that there is a third distinction and that is between different epistemological interests. ${ }^{26}$ While phenomenology aims to describe general acts of consciousness and has an anthropological attitude, sociology is an attempt to understand and discover the ways of thinking of actual human beings who live in concrete socio-historic situations. ${ }^{27}$ Therefore, Luckmann's metaphor of a "parallel action," (cf. Luckmann 2007a, p. 97; b, p. 131) meant to depict the interplay between phenomenology and sociology, is somehow twisted. The two disciplines do not share the same goal; rather, their different interests connect them in mutual amendment - perhaps a more promising relationship in the face of the necessity of the division of scientific labor.

\section{References}

Bergson, H. 1999. Duration and simultaneity. Manchester: Clinamen.

Blaukopf, K. 1996. Musik im Wandel der Gesellschaft. Grundzüge der Musiksoziologie. Darmstadt: Wissenschaftliche Buchgesellschaft.

Husserl, E. 1962. Phänomenologische Psychologie. Vorlesungen Sommersemester 1925. The Hague: Nijhoff.

Husserl, E. 1989. Ideas pertaining to a pure phenomenology and to a phenomenological philosophy. The Hague: Nijhoff.

James, W. 1981. The principles of psychology. Cambridge: Harvard University Press.

Luckmann, T. 1979. Phänomenologie und Soziologie. [Phenomenology and sociology]. In Alfred Schütz und die Idee des Alltags in den Sozialwissenschaften, ed. W.M. Sprondel and R. Grathoff, 196-206. Stuttgart: Enke.

Luckmann, T. 2007a. Aspekte einer Theorie der Sozialkommunikation. [Aspects of a theory of social communication]. In Lebenswelt, Identität und Gesellschaft, ed. J. Dreher, 91-111. Konstanz: UVK.

Luckmann, T. 2007b. Wirklichkeiten: individuelle Konstitution, gesellschaftliche Konstruktion. [Realities: Individual constitution, social construction]. In Lebenswelt, Identität und Gesellschaft, ed. J. Dreher, 127-137. Konstanz: UVK.

Luckmann, T. 2007c. Sinn in Sozialstruktur. [Meaning in social structure]. In Lebenswelt, Identität und Gesellschaft, ed. J. Dreher, 138-150. Konstanz: UVK.

Plessner, H. 1975. Die Stufen des Organischen und der Mensch. Einleitung in die Philosophische Anthropologie. Berlin/New York: Walter de Gruyter.

Schulz, W. 1994. Der gebrochene Weltbezug. Aufsätze zur Geschichte der Philosophie und zur Analyse der Gegenwart. Stuttgart: Neske.

Schutz, A. 1962. Symbol, reality and society. In Collected papers I: The problem of social reality, ed. A. Schutz, 287-339. The Hague: Nijhoff.

Schutz, A. 1964. Making music together: A study in social relationship. In Collected papers II: Studies in social theory, ed. A. Brodersen, 159-178. The Hague: Nijhoff.

\footnotetext{
${ }^{26}$ Besides the incongruity of subject matters hinted at above, sociology is concerned with social phenomena, whereas phenomenology is concerned with all kinds of human phenomena. But since there is an overlap, this reflection does not offer a selective criterion.

${ }^{27}$ Granted, sociology uses typification, but as a means of perception, not as its purpose.
} 
Schutz, A. 1996. Fragments toward a phenomenology of music. In Collected papers IV, ed. H. Wagner and G. Psathas, 243-275. The Hague: Nijhoff.

Schutz, A., and T. Luckmann. 1989. The structures of the life-world, Vol. II. Evanston: Northwestern University Press.

Weber, M. 1978. Economy and society: An outline of interpretive sociology. Berkeley: University of California Press. 